4 Gomez MR. The clinical examination. In: Engel AG, Franzini Armstrong C, eds. Myology. 2nd ed. McGraw Hill, 1994:746-63.

5 Brooke MH, Fenichel GM, Griggs RC, et al. Duchenne muscular dystrophy: patterns of clinical progression and muscular dystrophy: patterns of clinical progression and
effects of supportive therapy. Neurology 1989;39:475-81. 6 Dubowitz V, Heckmatt J. Management of muscular dystroDubowitz V, Heckmatt J. Management of muscular dystro-
phy. Pharmacological and physical aspects. Br Med Bull 1980;36:139-44.

7 Frost H, Klaber Moffett JA, Moser JS, Fairbank JCT. Randomised controlled trial for evaluation of fitness programme for patients with chronic low back pain. BMF 1995;310:151-4.

8 Malmivaara A, Hakkinen U, Aro $T$, et al. The treatment of acute low back pain-bed rest, exercises, or ordinary activity? N Engl F Med 1995;332:351-5.

9 Banker BQ, Engel AG. Basic reactions of muscle. In: Engel AG, Franzini Armstrong C, eds. Myology. 2nd ed. AG, Franzini Armstrong

10 Yamamoto $M$, Clemens PR, Engel AG. Mitochondrial DNA deletions in mitochondrial cytopathies: observaDNA deletions in mitochondrial cytopathies: 11 Schapira AHV. Mitochondrial cytopathies. Curr Opin

12 Oldfors A, Larsson NG, Lindberg C, Holme E. Mitochondrial DNA deletions in inclusion body myositis. Brain 1993;116:325-36.

13 Oldfors A, Moslemi AR, Fyhr IM, Holme E, Larsson NG,
Lindberg C. Mitochondrial DNA deletions in muscle fibres in inclusion body myositis. $\mathcal{f}$ Neuropathol Exp Neurol 1995;54:581-7.

14 Delisle MB, Laroche M, Dupont H, Rochaix P, Rumeau JL. Morphological analysis of paraspinal muscle: comparison of progressive lumbar kyphosis (camptocormia) and narrowing of lumbar canal by disc protrusions. Neuromuscul Disord 1993;3:579-82.

15 Muller-Hocker J. Cytochrome c oxidase deficient fibres in the limb muscle and diaphragm of man without muscula disease: an age-related alteration. $\mathcal{F}$ Neurol Sci 1990 100:14-21.

16 Corral-Debrinski M, Horton T, Lott MT, Schaffner IM, Flint Beal M, Wallace DC. Mitochondrial DNA deletions in human brain: regional variability and increase with advanced age. Nat Genet 1992;2:324-9.

17 Cortopassi GA, Arnheim N. Detection of specific mitochondrial DNA deletion in tissues of older humans. Nucl Acids Res 1990;18:6927-33.

18 Linnane AW, Marzuki S, Ozawa T, Tanaka M. Mitochondrial DNA mutations as an important contributor to ageing and degenerative disease. Lancet 1989;i:642-5.

19 Heffner RR, Barron SA. The early effects of ischaemia upon skeletal muscle mitochondria. $\mathcal{F}$ Neurol Sci 1978; 38:295-315.

20 Claque JE, Roberts N, Gibson H, Edwards RHT. Muscle imaging in health and disease. Neuromuscul Disord 1995; $5: 171-8$

\title{
NEUROLOGICAL STAMP
}

\section{Thomas Sydenham (1624-89)}

The 17th century physician, Thomas Sydenham, became known as the English Hippocrates. He studied medicine at Oxford where the dentist Robert Boyle and the physician and philosopher John Lock were his friends. John Lock gave a detailed account of trigeminal neuralgia in a series of letters in 1667 and Sydenham made contributions to the same condition. Sydenham's education was interrupted by the English Civil War. His father and four brothers were serving in Cromwell's army. Thomas also enlisted and served for four years as Captain of a Troop of Horse after which he returned to Oxford, gaining his MB in 1648. His medical studies continued at Montpellier where Rabelais (1490-1553) had earlier been Professor of Medicine.

Sydenham understood the need for careful bedside observation of clinical phenomena. His attitude towards his contemporaries was indifferent or scornful and he complained bitterly of the opposition and rejection of his own colleagues. His painstaking observations and excellent description of many diseases were recorded in his Observationes Medicae (Medical Observations) (1676). His fame largely rests on his first hand account of diseases including hysteria and his description of chorea minor. He was a sufferer from gout and his treatise on this subject Tractatus de podagra (1683) is considered a masterpiece. The Dissertatio Epistolaris (1682) contains his classic account of hysteria. Sydenham's description of chorea minor, which he saw as a kind of convulsion, is found in his Schedula Monitoria (1686).

Sydenham was one of the first to prescribe iron for anaemia and he popularised the use of quinine yielding cinchona bark introduced from Peru in the treatment of ague or malaria. Syphilis he treated by mercurial inunctions until free salivation occurred and he believed that it was the salivation, rather than the mercury, that wrought

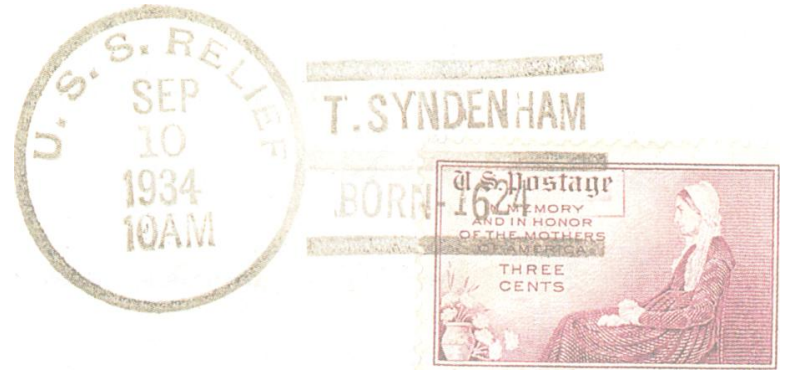

the cure. Opium was a favourite drug in the form of a tincture to which he added saffron, cloves, and cinnamon. "Sydenham's laudanum" as it was called remained a popular remedy for many years. His service to medicine was not to speculate but to lead people back to the bedside. His great success as a physician led Boerhave, when lecturing in Leyden, always to raise his hat on mentioning the name of Sydenham. He had a dignified ethical regard for his patients, holding himself "answerable to God" for their care. This may not have fitted easily into a modern management environment, but his comment "I have consulted my patients' safety and my own reputation most effectually by doing nothing at all" would, no doubt, have been looked upon more favourably.

After he left All Souls College he moved to London where he spent the rest of his life in private practice. Although he has not been honoured postally, he was honoured in this United States postmark of 1934, 310 years after his death. The postmark contains a spelling error. $\mathrm{He}$ died at his house in Pall Mall and was buried in St James's Church, Piccadilly, where the College of Physicians, in 1810 , erected a tablet to his memory. 